\title{
The Effect of Financial Performance on share prices with Earnings Per Share as a Moderation Variable
}

\author{
Dyatri Utami Arina Absari \\ Program Studi Akuntansi Fakultas Ekonomi STIE Widya Dharma Malang \\ *Coresponding Author \\ Email : dyatriutami@gmail.com
}

\begin{abstract}
This research was aimed to examine the effect of proxied financial performance on stock price by using Earning Per Share as its moderating variable. This research was to used historical data in predicting future stock prices using Financial Performance. The purpose of this study was to determine the effect of financial performance on stock price by using Earning Per Share as a moderating variable. For research sample was using the company listing on the Indonesia Stock Exchange for a period 2017-2019, to obtain a sample of 45 companies for the 3 period (2017-2019). Analysis of the data was used a simple regression analysis. Value, other variables that had no effect on stock price were liquidity, asset size, debt equity ratio (DER), return on equity (ROE). The company's financial performance that effects the stock price is Earning Per Share as a Moderating Variable's.
\end{abstract}

\section{Keywords: Financial Performance, Earning Per Share, Stock price}

\section{INTRODUCTION}

Capital markets as a means to shape capital and accumulate long-term funds to increase revenues that can be used to support national development financing. In 2008 during a global crisis which was on the rise of several factors such as the increasing world oil prices which resulted in increasing food prices worldwide, a crisis of bad credit and a decline in various investments in the banking world that knew Subprime Mortgage. The economic crisis that occurred in 2018, given the 10-year cycle that resembled the economic recession that took place in 1989 and the emergence of a trade war between the US and China.

Capital market developments are linked to the influence of the global crisis that hit in 2008 and the Trade war in 2018, then the challenges to be faced are increasing and future company growth will be increasingly uncertain (uncertainly) which will directly impact investors and company performance so that it will provide a very limited scope for investors who will increase capital planting on the stock exchange. With increasing interest rates futures as a result of monetary policy that makes investors look for other alternatives that are more fruitful in increasing investment in the stock market.

Looking at capital market developments associated with the influence of the global crisis that hit in 2008 and the Trade war in 2018, the challenges faced are getting heavier and the prospects of the company are increasingly unclear (uncertainly) which directly affects the behavior of investors and the performance of companies so as to provide narrow limits for increased capital planting in the shares of companies sold on the stock exchange. Rising interest rates due to monetary policy have caused investors to look for other alternatives that are more profitable for increasing the planting of capital sold by the exchange.

The purpose of investment decisions is to get a high level of profit with a certain level of risk. Investment decisions relate to the act of issuing a number of funds now in the hope of getting a return in the future with a greater amount. Investment decisions can provide benefits in the future if carefully considered. Investment decisions can help managers manage resources 
efficiently which can be concluded that the more efficient the resources used by companies, the greater the potential investors in giving confidence to buy their shares. Thus the more profit the company, the higher the value of the company which means the higher the prosperity that will be received by the company owner.

The value of the company can be increased through debt policy. The amount of debt used by companies is a policy that deals with capital structures (Brigham \& Gapenski, 1996). Therefore companies must be able to increase creditor confidence to lend funds to companies. Factors observed in this study were Liquidity, Assets Size, Debt Equity Ratio, Return On Equity, Earnings Per Share. In previous studies, it showed that there was no influence between EPS and systematic risk to share prices so in this study EPS was reused as an independent variable to prove the presence or absence of influence on share prices

\section{RESEARCH METHODS}

This research uses a quantitative approach, which is research that uses data in the form of numbers as a measuring instrument to find information about what is being researched. The aim of quantitative research is to develop and use mathematical models, theories and hypotheses related to the phenomenon that occurs. The data used in this study is secondary data. Data sources are obtained from company publications provided to the public through easily accessible media. The data collection technique in this study is by means of quantitative data documentation in the form of financial data, annual reports, and share prices of manufacturing companies that have been published by the company including:

1. List of companies registered with IDX and a list of companies included in LQ-45 in the form of annual financial reports (financial reports) (mannual reports).

2. IHSG data taken from (http://finance.yahoo.com).

The population in this study used companies in the LQ-45 field that were registered at IDX in 2017-2019. The sample method in this study was non-probability sampling, purposive sampling. The sample used by as many as 45 companies for 3 years, namely in 2017-2019 and selected using the method, the LQ-45 company whose shares are actively traded, has published a full report that has been audited and has a positive profit during 2017-2019.

\section{RESULTS AND DISCUSSION}

Based on statistical results it shows that there is a significant influence between independent variables consisting of liquidity, assets size, debt to equity ratio, return on equity, earning per share on share prices. The results of this study are consistent with previous research conducted by Parhusip, P. T and Silalahi, E (2017). This influence proves that information based on company fundamentals is useful for making stock investment decisions. Financial statements are able to affect securities prices because stock price movements are a reflection of management's performance so that financial statement information in the form of accounting variables (financial performance) can be used to assess companies.

The results of the hypothesis test partially show that financial performance that has a significant effect on share prices is Earning Per Share As a Moderation Variable and variables that have no significant effect on share prices are liquidity, assets size, DER, ROE, EPS, Beta shares. The results of the study did not match the results of research conducted by Yunita, R. et al. (2018), Jaza'i, et al. (2018), Parhusip, P. T and Silalahi, E (2017), Machdar, Nera M. (2015), Paramitasari, R. (2014). 


\section{Liquidity to stock prices}

Based on the results of the analysis of liquidity variables it does not have a significant effect on share prices. This research is consistent with research conducted by Parhusip, P. T and Silalahi, E (2017) and Machdar, Nera M. (2015) which shows that liquidity does not have a partial influence on share prices. The results of this study indicate that investors in investing do not consider the importance of a current asset ratio with current debt owned by the company. The company's liquidity ratio does not affect investors' perceptions of future profits. This research is not consistent with research conducted by Anjani, T., \& Syarif, A.D. (2019). It can be concluded that the higher the liquidity of a company will be the higher the value of the company.

Assets Size to the share price

Based on the results of the analysis, the assets size variable does not have a significant effect on stock prices. This research is not consistent with research conducted by Dhatt et al. (1999) and Endraswati, H \& Novianti, A. 2015 which show that assets size have a partial influence on stock prices because of the large number of assets size cannot be used to predict the level of share profits. Assets size describes the small size of a company that is indicated by total assets. Large-scale companies will find it easier to get loans compared to small companies. In this study, assets size was measured using total assets. Larger companies have greater growth than small companies. Based on the results of the analysis, the axets size variable partially has no significant effect on stock prices. The results of this study indicate that the small amount of assets size cannot be used to predict the level of stock profits (returns).

\section{DER against share prices}

Based on the results of the analysis, the DER variable does not have a significant effect on share prices. This research is supported by previous research conducted by Sondakh, et al. (2014) and inconsistent with research conducted by Anjani, T., \& Syarif, A.D. (2019), Parhusip, P. T and Silalahi, E (2017) and Machdar, Nera M. (2015) which show that DER has a partial influence on share prices. The results of this study indicate the lower the ratio of corporate debt can be used to predict the increase in the level of share profits (returns). DER will affect company performance and cause share price appreciation. DER that is too high has a negative impact on company performance, because an increasingly high level of debt means that the company's interest expense will be even greater and reduce profits (Ang, 1997). One of the main factors for using debt is because interest costs can be deducted in tax calculations, thereby reducing the actual cost of debt. However, if a large portion of the company's income has been spared tax due to accelerated depreciation or compensation for losses, then the tax rate will be low (if taxes are progressive) and profits due to debt use also shrink, so the higher the DER debt tends to reduce the price stock. In this case a growing company will need a lot of operational funds that cannot be met only from the company's own capital. These differing views cause less significant influence of DER on stock prices.

\section{ROE of stock prices}

Based on the results of the analysis, the ROE variable does not have a significant effect on share prices. This research is consistent with research conducted by Yunita, R. et al. (2018) Parhusip, P. T and Silalahi, E (2017) which show that ROE does not have a partial influence on share prices. This result indicates that the return on equity obtained by the company does not cause an increase in share prices, meaning that the increase or decrease in return on equity partially does not affect the share price. Investors do not see the small amount of ROE when it will invest, because in the view of investors ROE only describes capital returns and does not describe the upcoming market process. This research is not supported by research conducted by Machdar, Nera M. (2015) and Anjani, T., \& Syarif, A.D. (2019). 


\section{EPS to share prices}

Based on the results of the EPS variable regression analysis it has no significant influence and is positively related to stock prices. The coefficient of regression of the EPS variable is marked positive which indicates a positive relationship from the EPS which causes an increase in share prices. This research is consistent with research conducted by Jaza'i, et al. (2018) and Sondakh, et al. (2014) which shows that EPS does not have a partial influence on company value. This shows that an increase in EPS will drive an increase in share prices. This split contrasts with research conducted by Anjani, T., \& Syarif, A.D. (2019), Parhusip, P. T and Silalahi, E (2017), Endraswati, H \& Novianti, A. 2015 and Astuty, P. (2017).

The results of this study have supported the theory put forward by P. Jones in Husnan (2015: 328) which states that there is generally a strong correlation between profit growth (EPS) and stock price growth. This indicates the absence of deviations from the generally accepted theory, namely changes in profits, having a positive influence on the development of stock prices. The EPS variable that has a positive influence on stock prices shows that the company is able to increase investor prosperity.

\section{CONCLUSION}

This research aims to find out the effect of the company's financial performance on stock prices. Based on the results of the study it can be concluded that the company's financial performance has no effect on stock prices. The company's financial performance that affects stock prices is Earning Per Share as a Moderating Variable with Beta. This is because the stock beta is directly proportional to the price of individual shares so that if the stock beta which is a beta stock gauge rises then the share price will also rise.

The contribution of independent variables which is financial performance to share prices is small below $50 \%$, this is due to the share price formed by the supply and demand mechanism for the shares. Supply and demand occur because there are many factors, both factors that are specific to the stock such as the performance of the company and the industry in which the company is moving and macro factors such as the country's economic conditions, social and political conditions. In other words, investors not only make investment decisions based on micro conditions but also the company's macro conditions. This investment decision is also influenced by the individual character of the investor, whether long term investment or short term investment, where investors who want short-term profits are speculative because their investment decisions are strongly influenced by macro conditions

\section{REFERENCES}

Aletheari, I. A. M., \& Jati, I. K. (2016). Pengaruh Earning Per Share, Price Earnin Ratio, dan Book Value Per Share pada Harga Saham. E-Jurnal Akuntansi Universitas Udayana, 17.2, 1254-1282.

Ang, R. (1997). Buku Pintar: Pasar Modal Indonesia. Mediasoft Indonesia. 
Anjani, T., \& Syarif, A. . (2019). The Effect of Fundamental Analysis on stock prices using Data Panels; Evidence Pharmaceutical Companies listed on IDX. International Journal of Innovative Science and Research Technology, 4(7).

Arnova, I. (2016). Pengaruh Ukuran Kinerja ROA, ROE, EPS, dan Eva terhadap harga saham. Jurnal Ekombis, 1, 36-52.

Arvianto, R. A. S., Suhadak, \& Topowijono. (2014). Pengaruh Fundamental Makro dan Mikro Terhadap Nilai Perusahaan. Jurnal Administrasi Dan Bisnis (JAB), 13, 1-10.

Astutik, D. (2017). Pengaruh Aktivitas Rasio Keuangan Terhadap Nilai Perusahaan (Studi pada Industri Manufaktur). Jurnal STIE Semarang, 9, 32-49.

Astuty, P. (2017). The Influence of Fundamental Factors and Systematic Risk to Stock Prices on Companies Listed in the Indonesian Stock Exchange. European Research Studies Journal, XX(4A), 230-240.

Dhatt, S., Kim, \& Mukherji. (1999). Hubungan antara stock price dengan Berbagai kinerja keuangan di Pasar Modal Korea Selatan. Asia-Pacific Financial Markets Journal 6, 221 233.

Endraswati, H., \& Novianti, A. (2015). Pengaruh Rasio Keuangan dan Harga Saham dengan EPS sebagai Variabel Moderasi pada Perusahaan Manufaktur yang Terdaftar di DES. Jurnal Muqtasid, 6.

Foila, M. ., Yuliani, S., \& Agustina, H. (2019). The Effect of External Financing Needs and Suistainable Growth on Firm Value in Manufacturing Companies Registered on Indonesia Stock Exchange. Modern Economics, 86-93.

Ghozali, I. (2016). Aplikasi-Analisis Multivariate dengan Program IBM SPSS 23. Edisi 8 (8th ed.). Badan Penerbit Universitas Dipenogoro.

Gitman, L. J., \& Zutter, C. J. (2015). Principle of Managerial Finance. Pearson Education.

Gunadi, D. G., \& Ketut, W. . (2015). Pengaruh ROA, DER, EPS Terhadap. Universitas Udayana, 4.

Halim, A. (2015). Auditing: Dasar-Dasar Audit Laporan Keuangan, Edisi Kelima. Unit Penerbitan dan Percetakan STIM YKPN.

Hartono, J. (2014). Teori Portofolio dan Analisis Investasi, Edisi Kesembilan (9th ed.). BPFE.

Haryanti, Y., \& Murtiasih, S. (2019). The Effects of DER, ROA and DPR on Stock Price with EPS as the Moderating Variable in SOE. IOSR Journal of Business and Management (IOSR-JBM. e-ISSN: 2278-487X, p-ISSN: 2319-7668, 21(7), 01-08.

Hidayat, B. S., Suhadak, \& Rustam, R. (2015). Analisis Pengaruh Faktor-Faktor Fundamental Dan Teknikal Terhadap Nilai Perusahaan (Studi pada Perusahaan Consumer Goods 
Industry di Bursa Efek Indonesia Periode 2011-2013). Jurnal Administrasi Bisnis, 24, 110 .

Husnan, S. (2015). Dasar-dasar Teori Portofolio dan Analisis Sekuritas. AMP YKPN.

Indrawan, M. G., \& Raymond. (2019). Pengaruh Suku Bunga Sertifikat Bank Indonesia dan Nilai Kurs terhadap Risiko Sistematik Saham Perusahaan Sektor Keuangan yang Terdaftar di Bursa Efek Indonesia. JIM UPB, 1 .

Janitra, P. V., \& Wijaya. (2015). Pengaruh EPS, ROI, dan EVA Terhadap harga saham Perusahaan Otomotif di BEI. E-Jurnal Manajemen Unud, 4(7), 1831-1844.

Jaza'i, R., Subiyantoro, E., \& Harmono. (2018). Pengaruh EPS, ROI dan EVA terhadap harga saham Perusahaan Otomotif di Bursa Efek Indonesia (BEI). JSHP, 3.

Kasmir. (2016). Analisis Laporan Keuangan. Rajawali Persada.

Machdar, M. N. (2015). The effect of capital structure, systematic risk, and unsystematic risk on stock price. Entrepreneur Review, 14, 149-160.

Mayuni, I. A. E., \& Suarjaya, G. (2018). Pengaruh ROA, Firm Size, EPS, dan PER terhadap harga saham pada Sektor Manufaktur Di BEI. E-Jurnal Manajemen Unud, 7, 4063-4093.

Ni Nyoman D, S., \& Ni Luh, S. (2014). Analisis Pengaruh Beta Terhadap harga saham Periode Sebelum Dan Saat Krisis Global (Studi Pada Perusahaan Perbankan di BEI). E-Jurnal Akuntansi Universitas Udayana 7.1, 19-32.

Nurdin, D., \& Kasim, M. Y. (2017). Moderator Effect of Corporate Governance on the Relationship of Financial Performance and Dividend Policy, and Its Impact on Firm Value in Indonesia Stock Exchange. International Journal of Economics \& Management Sciences, 7(1).

Paramitasari, R. (2014). Pengaruh Risiko Sistematis Dan Risiko Tidak Sistematis Terhadap Expected harga saham Dalam Rangka Pembentukan Portofolio Saham Lq-45 Yang Terdaftar Di Bursa Efek Indonesia Dengan Single Index Model Periode Tahun 2009. Jurnal Organisasi Dan Manajemen, 10, 78-83.

Parhusip, P. T., \& Silalahi, E. (2017). Pengaruh Faktor Fundamental Dan Risiko Sistematik Terhadap harga saham Pada Perusahaan Manufaktur Yang Go Publik Di Bursa Efek Indonesia. JRAK, 3 .

Pinatih, L. P. W. K., \& Lestari, P. V. (n.d.). Pengaruh EPS, ROE, Risiko Sistematis Terhadap harga saham Perusahaan Otomotif di BEI. . . E-Jurnal Manajemen Unud 3(10): 29903002 .

Prasetyo, Y., Athoillah, M. A., \& Rosadi, A. (32019). Pengaruh Variabel Ekonomi Makro (inflasi, kurs rupiah dan fluktuasi harga emas dunia) terhadap harga saham Syariah. Istinbáth Jurnal Hukum Dan Ekonomi Islam, 18, 1-232. 
Putra, F. E., \& Kindangen, P. (2016). Pengaruh Return On Asset (ROA), Net Profit Margin (NPM), Earning Per Share (EPS) terhadap harga saham Perusahaan Makanan dan Minuman yang Terdaftar Di Bursa Efek Indonesia (Periode 2010-2014). Jurnal EMBA, 4, $235-245$.

Quaye1, I., Mul, Y., Abudu1, B., \& Agyare, R. (2016). Review of Stock Markets' Reaction to New Events: Evidence from Brexit. Journal of Financial Risk Management, 5, 281-314.

Raharjo, D., \& Muid, D. (2013). Anaisis Pengaruh Faktor Fundamental Rasio Keuangan Terhadap Perubahan Harga Saham. Diponegoro Jurnal Of Accounting, 2, 1-11.

Risdiyanto, \& Suhermin. (2016). Pengaruh ROI, EPS, PER terhadap harga saham pada Perusahaan Farmasi. Jurnal Ilmu Dan Research Manajemen, 5, 1-16.

Rustan, Rahman Mus, A., Chalid, L., \& Nur, A. N. (2018). The Influence of the Structure of Ownership and Dividend Policy of the Company (The Quality of the Earnings and Debt Policies are Intervening Variable): Empirical Study on Manufacturing Companies Listed on the Indonesia Stock Exchange. International Journal of Innovative Science and Research Technology, 3(18).

Sapar, J. F. (2017). Pengaruh Faktor Fundamental Keuangan Terhadap Beta Saham pada Perusahaan Manufaktur yang Go Publik di Bursa Efek Indonesia. Jurnal Ilmiah Ekonomi Bisnis, 3, 335-353.

Shakeel, M., \& Ali, G. (2018). The relationship between fundamental analisys and stock prices based on the panel data analysis; evidence from karachi stock exchange (KSE). Research Journal of Financial and Accounting, 9.

Sondakh, J., Pontoh, W., \& Tangkuman, S. (2014). Pengaruh Rasio Keuangan atas harga saham pada Perusahaan Industri Manufaktur Di Bursa Efek Indonesia. Jurnal LPPM Bidang EkoSosBudKum, 1.

Sugiyono. (2016). Metode Penelitian Kuantitatif, Kualitatif, dan Kombinasi (Mixed Methods). Afabeta.

Sugiyono. (2015). Metode Penelitian Bisnis. Alfabeta.

Sukhemi, I. N. (2015). Pengaruh Risiko Sistematis dan Likuiditas terhadap harga saham pada Perusahaan Manufakturnyang terdaftar di BEI. Jurnal Akuntansi, 3.

Syariah, K. P., Muamalat, P., Syariah, F., Hukum, D. A. N., Syarif, U. I. N., \& Jakarta, H. (2014). Pengaruh Faktor Fundamental Dan Risiko Sistematis Terhadap harga saham Perusahaan Pada Jakarta Islamic Index. 109046100224.

Tandelilin, E., \& Lantara, I. W. N. (2001). Stabilitas dan Prediktabilitas Beta Saham: Studi Empiris di Bursa Efek Indonesia. Jurnal Ekonomi Dan Bisnis Indonesia, 16, 164-176. 
Email : editorijhess@gmail.com

Wagner, A. ., Zeckhauser, R. ., \& Ziegler, A. (2018). Company stock price reactions to the 2016 election shock: Trump, taxes, and trade. Journal of Financial Economics, 130, 428451.

Wahidhani, E. H. (2015). Moderating Variable At Financial Ratios : Evidence From Indonesia. International Jurnal Of Business Quantitative Economics And Applied Management Research, 2(4).

Yunita, R. (2018). The Influence of Internal and Macro-Economic Factors on the Stocks Return with Stock Beta as the Intervening Variable (Case Study on Property, Real Estate, and Building Construction Companies Listed on Indonesia Stock Exchange for the Period of 2012-2016. BILANCIA, 2 